Article

\title{
Sustainable Growth Approaches: Quadruple Helix Approach for Turning Brașov into a Startup City
}

\author{
Oana Bărbulescu and Cristinel Petrişor Constantin * \\ Faculty of Economic Sciences and Business Administration, Transilvania University of Brașov, \\ 500036 Brașov, Romania; oana.barbulescu@unitbv.ro \\ * Correspondence: cristinel.constantin@unitbv.ro; Tel.: +40-0727-39-2380
}

Received: 4 September 2019; Accepted: 30 October 2019; Published: 4 November 2019

check for updates

\begin{abstract}
The aims of this study are to identify large companies' role in stimulating local entrepreneurship, and higher education institutions' contribution of fostering entrepreneurial activity in order to achieve an innovative ecosystem and turning Brasov into a startup city. To address the research questions, exploratory research was conducted among 18 representatives of companies and public institutions active in Brasov city, Romania. The findings confirm that large companies engage startups by collaborative models being also available to outsource a series of activities to entrust the startups with. These collaborations bring many opportunities to startups to scale up faster by using large companies' resources and the routes to the markets on which they operate. Furthermore, this research reveals the need for a better synergy between education, research, and practice and, consequently, an improvement of the academic curriculum. It also exemplifies the need for joined theory and practice to influence policymakers in developing policies to create a sustainable entrepreneurial ecosystem. The empirical results have implications for both the entrepreneurship literature and entrepreneurship policies.
\end{abstract}

Keywords: startup; entrepreneurship; sustainable growth; startup city; business ecosystem; qualitative research

\section{Introduction}

The entrepreneurial ecosystem has evolved over the last decade, not only because of technological advances that have created unprecedented opportunities, but also owing to the active sharing and dissemination of a growing number of tools and methodologies designed to support complexity and entrepreneurial risk [1].

The concept of entrepreneurship covers a wide range of organizational and individual activities, but it is most often associated with an entrepreneur's decision to start a new business. For this reason, the previous literature has paid more attention to the entrepreneurial activity involved in starting up new businesses [2]. We follow these contributions, although different forms of entrepreneurship are not anonymous in the literature. According to Drucker [3], the entrepreneurs can also be found in corporations; "entrepreneurs ... create something new, something different; they change or transmute values. An enterprise also does not need to be small and new to be an entrepreneur. Indeed, entrepreneurship is being practiced by large and often old enterprises." [1].

Additionally, some authors have shown that "entrepreneurship is a complex phenomenon; sustainable entrepreneurship is perhaps more so, given the presence of commercially viable ventures that pursue economic, social and environmental outcomes concurrently." [1,4].

The recent literature introducing the concept of sustainable entrepreneurship has integrated the social and environmental aspects [2,5], simultaneously linking the entrepreneurial process to the concept of opportunity recognition, which is in many ways closely related to innovativeness [2]. 
Entrepreneurship and innovation are the keys to achieving lasting economic growth in the long run. Innovation is essential for sustained corporate success. In terms of employment and sales, innovative businesses grow twice as fast as those failing to innovate. A visible trend in recent years has been the increasing movement towards open innovation and, especially, collaboration with startups. This is particularly noticeable in high technology industries, where innovation rates are rapid and where knowledge is shared between several organizations, making it more difficult for a single entity to innovate without collaborating [6]. In this research, we concentrate on four models of collaboration: gaining "exposure" to startups (potentially through one-off events such as hackathons and sponsoring co-working spaces), acceleration programmes, corporate venture capital programs, and acquisitions.

Constantly changing markets due to globalization have meant that knowledge and innovation have become key factors in the sustainable development of any economy, and industries have become increasingly dependent on academic research to generate marketable innovations and economic growth $[7,8]$. This new need for innovation has given rise to the triple helix theory. This model is associated with the concept of academic entrepreneurship, because seeks to define the new entrepreneurial dimension of universities, in which they and other knowledge-producing organizations play a strong role $[7,9]$. This theory was further developed to the quadruple helix, which involves a collaboration between governance, academia, industry, and citizens.

This paper contributes to the literature on academic entrepreneurship by stressing an aspect that is largely overlooked; that is, large companies' role in stimulating local entrepreneurship and higher education institutions' contribution of fostering the entrepreneurial activity, starting from quadruple helix theory. Thus, bearing in mind the theoretical premises outlined above, the aim of this paper is to offer a better understanding of how companies engage with startups or boost their existing collaborative activities, by finding answers to the following research questions. (Q1) What are the ways in which the development of startups can be stimulated by the large companies? (Q2) How can the higher education institutions contribute to the development of the entrepreneurial ecosystem?

As research hypotheses, in the authors' opinion, corporates engage startups through various mechanisms, often adapting existing collaborative models to new approaches. Additionally, higher education institutions play an important role in helping students and graduates who intend to start a business as a career option. In this respect, we have studied to what extent the Transilvania University of Brașov can offer targeted assistance to generate, evaluate, and act upon new ideas, building the skills necessary for successful entrepreneurship.

Using a qualitative research based on semi-structured in-depth interviews, the results suggest that Brasov City could turn into a startup city thanks to many business opportunities in which the entrepreneurs can invest: the Automotive industry, Information Technology (IT), Tourism, and so on. The findings also emphasize a determinant role played by higher education institutions in the development of such startup cities. Thus, the above stated hypotheses have been confirmed.

The article has the following structure: Section 1 provides an introduction in the field, Section 2 outlines the theoretical framework, Section 3 explains the methodology applied in this research, Section 4 presents the empirical evidence and discusses the results, and Section 5 concludes the paper and presents the limitations of this study.

\section{Theoretical Background}

\subsection{Sustainable Entrepreneurship}

Increasing attention has been given by scholars to the connection between sustainable development and entrepreneurship [10]. Sustainable entrepreneurship is today a major concern that began with sustainable management and an entrepreneurial initiative; in recent years, researchers from different backgrounds that have focused on this concept have approached it from different academic perspectives [10-12]. 
Previous researchers [1] have identified a four-category typology of sustainability-oriented entrepreneurship: ecopreneurship (environmentally oriented entrepreneurship), social entrepreneurship (focused on addressing social problems), institutional entrepreneurship, and sustainable entrepreneurship.

The early literature on sustainable entrepreneurship was basically focused on the entrepreneurial activity and its relationship with environmental problems and solutions [10]. Some authors [13-16] have shown that sustainable entrepreneurship is practiced by entrepreneurs that use business tools to preserve space, save endangered species, develop wildlife habitats, and improve environmental quality.

Starting with the beginning of the 1980s, ecopreneurship, also known as environmental entrepreneurship, is a phenomenon that focuses on environmental issues, emerging from the ever-growing understanding of the business' sustainability value. Later on, this premise received growing attention, as reflected in the growing literature covering it. Schaper [17], highlighting the three common features of all ecopreneurial activities, claims that, first of all, they are entrepreneurial activities; secondly, these activities have a positive net impact on the environment; and ultimately, they are intended, because the positive environmental impact is deliberate and not accidental, although the level of significance of the environmental objectives may vary significantly from one business to the other.

Social entrepreneurship has often dealt exclusively with the social aspect of sustainable entrepreneurship [18-20]. Out of the four previously mentioned categories, this one probably draws the scholars' greatest attention. From its initial focus on the definition and distinctive characteristics, this interest moved to investigating the social enterprises' management and performance [21]. In terms of its intrinsic social objective, its definitions range from broad, including for-profit, non-profit, as well as hybrid platforms, to narrow, mostly considering non-profit applications [22]. From a more complex perspective, when viewed through the broader lens of social entrepreneurship, and in particular in the context of commercial entrepreneurship, the duality of combining social value with financial sustainability has always been one of the main challenges for the entrepreneurs, in their attempt to overcome the traditional dichotomy between the creation of social values and financial performance.

Additionally, some authors in social entrepreneurship literature focused only on case analyses of successful non-profit social organizations [23] or studied the opportunities for social entrepreneurship in the context of globalization [24].

The few attempts made to analyze in depth institutional entrepreneurship [25] suggest that this category of entrepreneurship is initiated by entrepreneurs who are looking to change institutional settings, to transform existing societal, regulatory, and market institutions or to create new ones. What draws attention to these classifications is the absence of the dimension of innovativeness [2].

Following these seminal contributions, later scholars introduced the concept of sustainable entrepreneurship, defining it as "the realization of sustainability innovations aimed at the mass market and providing benefit to the larger part of society" [25]. By attempting to conceptualize a framework to support sustainable entrepreneurship, researchers recently defined this phenomenon as those entrepreneurial activities that do not harm the ecological and social environments and are expected to consider and work toward achieving all triple bottom-line goals [26].

A new approach to sustainable entrepreneurship is the triple bottom-line theory, which was originally developed to understand the tie between entrepreneurship and sustainable development, stressing that the companies' sustainability is evidenced by the main activities carried out in their environment, the impact assessment, the achievement of the objectives, and the transparent communication of the results, with all of these activities being geared to satisfying the vital needs of people by means of applying the concept of creative destruction [27] as a precondition and driving force in the transition to a more sustainable entrepreneurial ecosystem [10].

On the basis of the triple bottom-line perspectives, also known as triple helix, startups are considered a key factor in supporting the sustainable economy because, through their innovative capacity, they can introduce more environmental and social solutions [28]. As small and medium 
entreprises (SMEs) account for about $95 \%$ of all companies around the world, it is important to point out the role they generally play in the percentage of employment in most countries. Although the individual impact generated by SMEs is rather small, their joint impact is essential and indispensable for most regions. Owing to their limited resources, their understanding of sustainable practices may differ from that of the large enterprises $[29,30]$. Sustainable entrepreneurship is not just about setting up new companies to explore opportunities and market threats, to generate employment, and to improve products and processes, it is also about consciously analyzing the economic, social, and environmental impact that corporations' performance has on territories.

A new perspective on sustainable entrepreneurship is developed by those academics [31] that support the concept of quadruple helix, emphasizing the players' multiple and simultaneous roles. Quadruple helix innovative means that the public sector, academia, industry, and citizens collaborate to drive structural changes far beyond the scope that any organization could achieve on its own.

\subsection{Key Features of Startup Cities}

In the current research, the term startup city refers to a city that has produced some mature results in terms of startups, more precisely of innovative firms with minimally stable operations, and not only a city with a high concentration of scaleups. A scaleup company is considered a tech company that has raised over one million dollars. The cities that include a large number of startups as well as the highest concentration of scaleups in their respective country are included in the startup city hubs category [32].

In order to develop a startup city that can stimulate the sustainable development of a region, a proper business ecosystem should be established inside the city's boundaries. Such ecosystems have to include more stakeholders like large companies, authorities, higher education institutions, and research centers. These stakeholders could cooperate in order to obtain sustainable growth of the business ecosystem [33]. Thus, stakeholders' mutual support contributes to establishing a multi-actor network that is dynamic in time, so as to adapt to the business environment and better manage the business ecosystem [34].

The main goal of a startup city is to develop the business environment of a region with future beneficial effects on the local market, such as business development, new jobs for residents, and new established startups. Further on, such an evolution can contribute on a larger scale to the national economic development [35]. However, in order to reach this goal, proper management of the business ecosystem should be practiced by involving the actors in a continuous negotiation process meant to encourage the diversity of ideas that could lead to the best decisions [36].

Creating a successful startup city is not so easy. In the literature, the large number of startups that fail in the first years of existence us stressed, which is mainly owing to a poor understanding of a competitive market and an improper product portfolio [37]. The establishment of startups and their success in a certain business ecosystem depend on many factors, but the existence of potential customers is a strong incentive for entrepreneurs [38,39]. Other factors like the business plan, startup incubators, business location, and surrounding business community can stimulate startups' development [40]. In this respect, the main actors of a startup city can assist the new companies in finding the best ideas of products that can be addressed to viable market segments [35].

Collaboration between large companies and startups is becoming an integral part of the startup ecosystem, being a vital part of the innovation generation process. Many companies begin their startup engagement by increasing their exposure to startups and entrepreneurial culture. This is often done by running one-off startup events, such as hackatons and competitions, or through the provision of free tools, entrepreneurial resources, and sponsorship. These are relatively "light-touch" ways of experimenting startup engagement, gaining an initial idea of technologies and capabilities that startups offer without longer-term commitment. Accelerators are a step beyond "exposure", typically providing substantial support to startups, as well as deeper engagement with corporations. In this respect, accelerators programmes offer systematic and professional assistance, not only providing tangible resources such as funds or office space, but also offering know-how, mentorship, and 
feedback from experienced entrepreneurs, business angels, coaches, and corporate executives [41,42]. Representing the third model of open innovation, corporate venture capital programmes have become an important instrument for accessing valuable knowledge from entrepreneurial ventures. Because the knowledge necessary to generate innovation may likely reside outside the boundary of large companies (entrepreneurial startups being a valuable source of such knowledge), corporate venture capital programmes are instruments used in harvesting innovation from the entrepreneurial ventures in certain environments [43]. Last, but not least, we also consider in our theoretical framework the relevance of acquisition as an open innovation model. The large companies realize that the acquisition of young companies is an effective way of building up next generation products, expanding to new markets, or simply acquiring new (digital) capabilities. Companies use an adaptive and flexible approach to incorporate acquired startups into their broader business strategy; the way in which acquired firms are incorporated depends on the maturity of startups' capabilities, enterance on the new market, product development, and purpose of acquisition. Depending on the reason for the acquisition, startups either join an existing unit or continue to operate as an independent unit.

Additionally, universities play an important role in startups' success by know-how transfer, business education, and specialty assistance for entrepreneurs [44].

Some startup cities need to deal with their relatively limited size and resources and develop strategies to achieve the critical mass. Sustainable startup city growth plans must be built upon two pillars:

1. Specialization: the specialization of cities on specific verticals; the smaller the city, the lesser the resources to support multiple specializations; startup cities should develop a strategy of specialization on specific verticals (industries or services).

2. Partnerships: the strategic connection with other cities; critical mass can be achieved by leveraging the benefits of agglomeration through either of the following

(1) international connections with other cities that share similar focus/specialization;

(2) local alliances with nearby cities.

Anyway, a lean approach based on pilot projects is also recommended to optimize the use of public resources and mobilize investments based on clear milestones [32].

\subsection{Entrepreneurship Education and Innovation}

The early literature on entrepreneurship education highlighted only the function of fostering leadership [45]. Other contributions to the field focus primarily on its organizational building and high achievement as main functions [46]. Research on entrepreneurship education literature focuses most on how it involves creation and operation of an enterprise [47] and on the process of creating value for customers by exploiting untapped opportunities [48]. Moreover, entrepreneurship education literature is also concerned with the interrelationships among an entrepreneur's personality, strategic orientation and innovation [49], whereas it simultaneously links the process of entrepreneurship education to a strong and positive orientation towards growth in wealth, knowledge, and employment [50]. The recent literature on entrepreneurship education has consequently attempted to point out the function of innovation [51].

According to Gautam and Singh [52], entrepreneurship education develops certain skills, creating competencies to shape the future society and its own life simultaneously, playing the role of a catalyst for socio-economic change. In this train of thought, it supports potential entrepreneurs in identifying and tracking opportunities by focusing on creating an entrepreneurial culture without being limited to stimulating startups, innovative initiatives, and new jobs. The research literature suggests that institutional quality is one of the most powerful drivers of socioeconomic development, which has a major impact on the pace of innovation and sustainable economic development [53-55]. 
In the last decade, the mission and mandate of higher education to generate and transfer knowledge to society have become more complex and their activities have broadened [56]. For instance, higher education institutions have considerably expanded their research and development activities. They have interacted more with other players of innovation ecosystems, have explored innovative teaching methods finding ways to stimulate the entrepreneurial mind-sets, and have implemented the so-called entrepreneurial teaching and learning. This involves learning about how to start a new company and acquiring the skills and competencies for developing entrepreneurial mind-sets. These are often associated with the ability to deal with problems, by resorting to manifold methodologies and inter-disciplinary approaches; to problem-solving skills; and, in more general terms, to soft skills (communicating, managing, teamworking, and so on).

For this reason, entrepreneurial education does not refer only to specific issues such as the content of study programmes, the way in which the content is offered (separate courses, embedded in all curricula), or the number of students enrolled to these programmes. This concept concerns a wider context in which one must take into account the accumulation of lifelong skills and the way in which these contribute to the quality of life by building the human and social capital needed to promote knowledge sharing, as well as collaboration with relevant key factors [56].

Knowledge sharing is an important catalyst for organizational innovation, the advancement of teaching and research, and local development. In order to directly apply and exploit knowledge for the benefit of the social, cultural, and economic development, innovative and entrepreneurial education institutions cannot operate in an isolated manner, but only closely linked to other players (large companies, small and medium enterprises, cluster associations, technology and science parks, government agencies, and other research organizations) [56]. In this context, it is clear that a holistic approach is needed to promote entrepreneurial and innovative education.

\section{Materials and Method}

\subsection{Setting the Context: Brașov City's Entrepreneurial Ecosystem}

\subsubsection{Center Development Region}

Brasov is one of the six counties included in the Center Region, which is one of the eight Romanian development regions, named as follows: Bucharest-Ilfov (which includes Bucharest, the capital city of Romania), North-East, North-West, West, Center, South-East, South-West Oltenia, and South-Muntenia. While Bucharest-Ilfov is the most developed region, the Center Region is closer from the median position in terms of economic indicators, having high opportunities of future development. Regarding the business demography, the Center Region was placed in third position in 2017 as regards to the number of new born enterprises according to the Romanian Institute of Statistics [57]. The evolution of the newly created active enterprises from 2008 to 2017 is presented in Figure 1.

It can be seen in Figure 1 that, after a decrease in the number of new born enterprises from 2011 to 2014, starting with 2015, there was a constant increase in this number in the Center Region. Thus, the increasing rates of the number of new born enterprises in the Center Region as compared with the previous year were as follows: $73.5 \%$ in 2015 (from 6809 enterprises to 11,816 enterprises); $11.7 \%$ in 2016 (up to 13,204 enterprises); and 15.6\% in 2017 (up to 15,263 enterprises).

Regarding the survival rate (see Figure 2), we can observe that even if the number of new born enterprises increased from 2014 to 2017, the percentages of companies that survived after the first year decreased significantly: from $85 \%$ in 2014 to $71.2 \%$ in $2015,71.6 \%$ in 2016 , and $68.7 \%$ in 2017 . This evidence confirms the findings of other studies mentioned in the literature [37]. Nevertheless, the survival rate in the Center Region was one of the highest among the Romanian development regions. In conclusion, Brasov County as a member of the Center Region has a high development capacity as far as entrepreneurs are committed to invest in new firms that can become startups. 


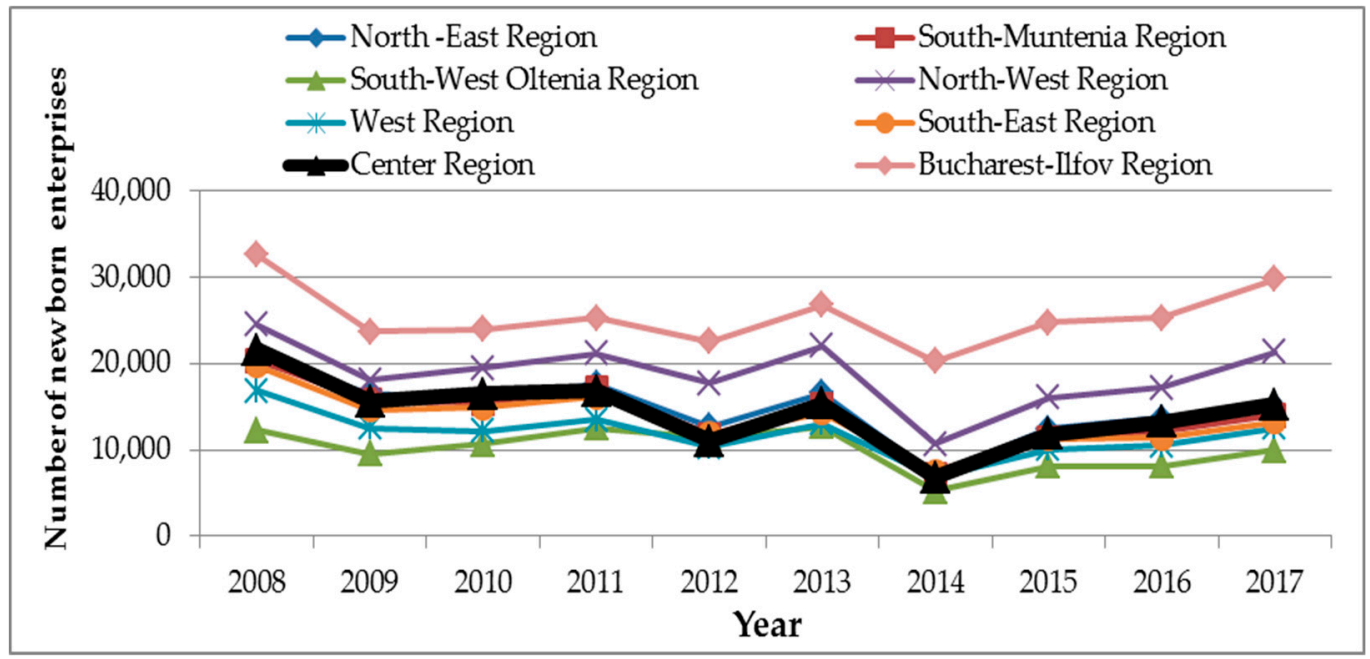

Figure 1. The evolution of new born enterprises per Romanian development region in the period 2008-2017. Data source: http://statistici.insse.ro:8077/tempo-online/\#/pages/tables/insse-table.

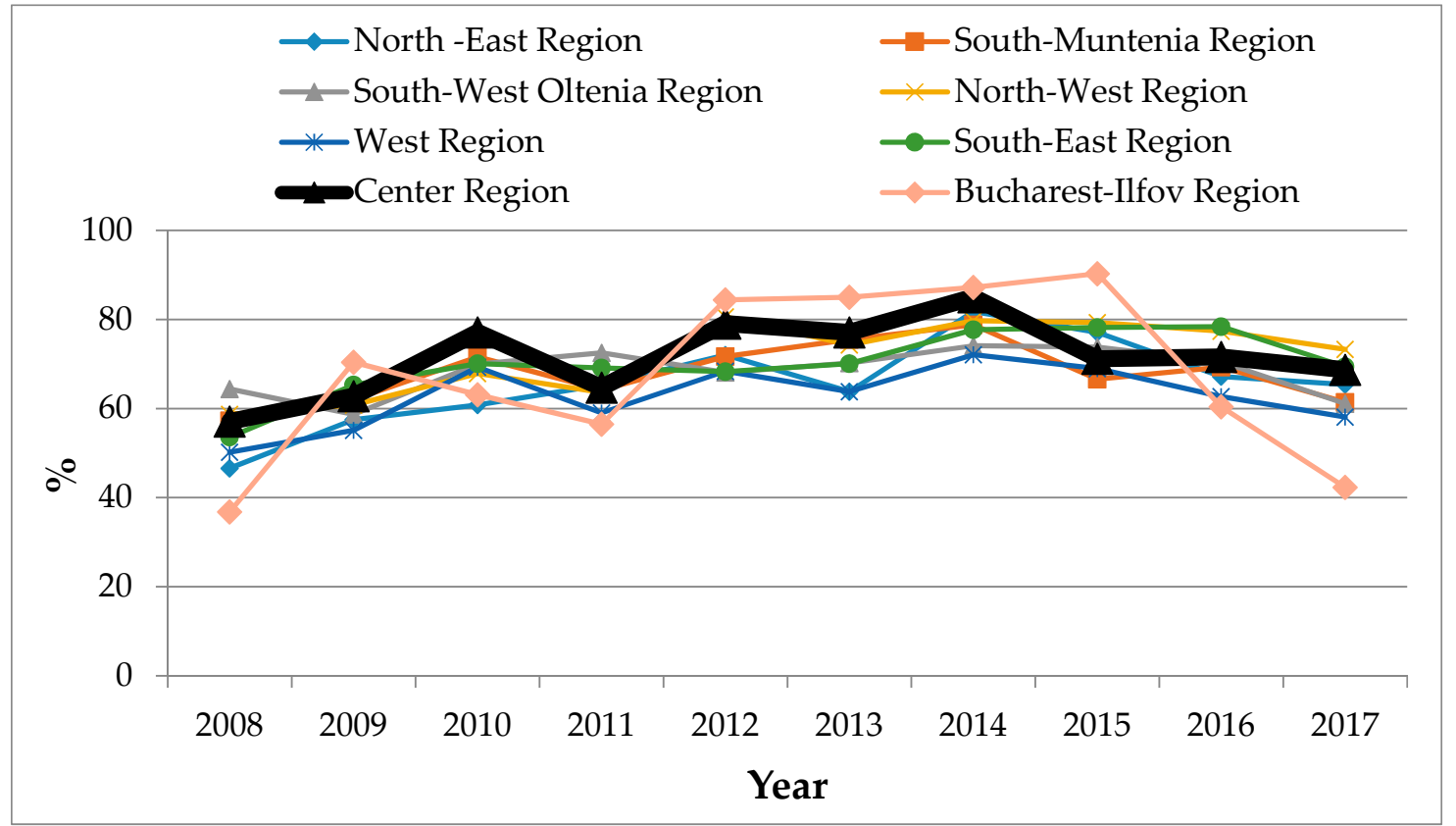

Figure 2. The percentage of new born enterprises surviving after their first year per Romanian development regions (period 2008-2017). Data source: http://statistici.insse.ro:8077/tempo-online/\#/ pages/tables/insse-table.

\subsubsection{Brașov County and Brașov City}

Brasov County is the most developed from an economic point of view in the Center Region (which counts six counties), with the highest gross domestic product (GDP) according to the regional statistics [57]. As mentioned in the last report, available for 2016, the GDP recorded by Brasov County represents more than $30 \%$ of the GDP at the regional level. Brasov was also one of the most developed counties in Romania during the Communist era, with a predominant industrial sector. After the fall of communism in 1989, almost all of the industrial companies failed as a result of poor technological development. But in the last years, the local economy has been relaunched mainly as result of big foreign investments, especially in the automotive industry. In 2017, in Brasov, there were 69 active large companies (enterprises with more than 250 employees). Among these companies, there are some important foreign subsidiaries. 
Regarding the business demography in Brasov city and its metropolitan area, a total of 3771 newborn enterprises were founded in 2018 and 3953 enterprises in 2017, according to the official statistics [58]. In the same period, the number of new enterprises recorded in Bucharest, the capital city of Romania and the most developed economic center, was five times higher than in Brasov. Such a context represents a challenge for Brasov city in its goal to become one of the most important poles of economic development. In order to reach this goal, it is necessary to encourage entrepreneurship and stimulate the establishment and development of startups. In this respect, large companies can have a high contribution because they can cooperate with startups in their daily activities on a permanent basis or for specific projects. Thus, the outsourcing of different activities undertaken in the present by the large companies could contribute to the startups' development. At the same time, such cooperation can contribute to a higher efficiency and competitiveness at the level of large companies, which can focus better on their core activities while other activities can be outsourced [59].

Keeping in mind the above-mentioned issues, we focused on finding out the opinions of the managers of some large companies on how such corporations may contribute to the process of turning Brasov into a startup city. In this respect, we conducted qualitative research based on semi-structured, in-depth interviews.

\subsection{Research Methodology}

Starting with the context of Brașov's entrepreneurial ecosystem and the main topics debated in literature, we tried to find answers to our research questions. In this respect, the following objectives were established: (1) identifying managers' opinions about the possibility of developing startups in Brassov; (2) identifying managers' opinions about the ways in which the large companies can contribute to the development of startups; (3) identifying managers' opinions about the ways in which the Transilvania University of Brasov can contribute to the development of an entrepreneurial ecosystem. The first and the second objectives are meant to find answers to the first research question, while the third objective is related to the second question.

In order to reach the research objectives, exploratory research was conducted among 18 managers of different companies and institutions that operate in Brasov city. Twelve of our sample members were representatives (Chief Executive Officer (CEO), Chief Innovation Officer, or Chief Digital Officer) of well-known large companies that succeeded in various fields of activity, and were selected in order to have a wide spectrum of opinions regarding the research topic. These fields of activity were as follows: IT (two companies), oil industry (two companies), automotive industry (four companies), wood industry (two companies), and trade (two companies). Another four participants in our research were representives of startups (all of them were startups' owners) and two others were from public institutions (a general manager of the Chamber of Commerce and Industry of Brassov and an executive manager of an industrial companies' union).

The qualitative data were collected using individual in-depth interviews. The interviews were conducted using a semi-structured interview guide that contained three major topics of discussion, divided in several subtopics of discussion in order to obtain an in-depth immersion in the researched problem. All participants, irrespective of the size of the enterprise they represented, were invited to discuss the same topics by expressing their own point of view. They were introduced using open-ended questions or invitations to discuss some topics in detail. The participants were invited to state whatever they wanted to concerning the discussion topic, to give arguments, and to make reference to their experience and their predictions about the future economic development. They were assured about the confidentiality of the answers and ideas, that all these answers are very valuable for the research results, and that there are no wrong ideas even if they seem to not be applicable. The discussions were free, with every topic being introduced in the debate only when the managers did not address it. The main topics and subtopics included in the interview guide were as follows:

(1) Which are the main incentives of startup development in Brasov city (the most attractive economic fields; problems faced by startups; ways of sustaining startups development)? 
(2) How do your companies cooperate with local startups in the business activities (current business relationships; advantages to cooperating with startups; establishing co-working spaces; the strategy of acquiring startups; new products or technologies jointly developed; organizing competitions for business ideas)?

(3) The role played by the Transilvania University of Brasov in developing the entrepreneurial skills of students and in establishing new startups (entrepreneurial education; ways of cooperation between university and business environment in developing entrepreneurship).

The data resulting from the semi-structured interviews were analyzed using content analysis [60]. Each theme contained in the interview guide was analyzed in depth and the answers' contents were compared in order to find similarities in the respondents' discourses. The answers with similar meanings were grouped into categories, which received different codes. These categories were included in a table that contained the discussed topics in rows and the interviewees in columns. The dominant contents of answers were identified using the horizontal analysis of every table row. In order to find associations between respondents' discourses, a vertical analysis was also used. Finally, the research results were grouped on every research objective addressed by the topics included in the interview guide.

The reliability testing of the research results was done using "data triangulation" [61]. For each objective, the information obtained from managers of large enterprises was compared to that obtained from the representatives of startups and public institutions, as well as to the results of other studies presented in the specialty literature.

\section{Results and Discussion}

The research results are structured on every objective stated above in order to find answers for the research questions. The first two objectives address the first research question, while the third one is meant to obtain answers to the second research question.

(O1) Identifying managers' opinions about the possibility of developing startups in Brașov

This topic of discussion approaches three aspects: the fields considered attractive in order to start a new business in the area of Brașov; the problems faced with Romanian startups; and the facilities to be offered to the newly established companies. The authors aimed at identifying the interviewees' opinions about the fields considered to be the most attractive to start a new business in the area of Brașov. The interviewed managers emphasized the importance of two sectors: firstly, a forward-looking field is one in which new technologies are developed, considering that the startups in the field of IT software development are the ones with the highest scaling potential; secondly, because the automotive industry is the most developed in the area of Brașov and the major players in this sector are the large foreign corporations, the startups capable of identifying the problems faced by these companies, and of finding solutions by creating services offered to them, will have a future in the market. In this regard, two directions were anticipated: the creation of startups that provide logistics and mainly transportation services for large manufacturers and the creation of startups that design and develop new components and IT solutions for autonomous machines, which will enter on the market in the near future.

Most managers pointed out that a large number of companies were established in the field of tourism, a sector of little profitablity. This suggests that although not very attractive, this field was the easiest to approach.

Some interviewed managers mentioned that the medical sector, which has developed strongly in the recent years in Brașov, still has growth potential, and others consider that the entertainment sector is not explored enough, although it has potential.

As for the problems faced by startups, the interviewed managers emphasized two aspects: the absence of an adequate infrastructure and a legislation that does not encourage entrepreneurship in Romania. The lack of an airport and a highway; cultural problems that discourage entrepreneurship; 
the lack of social support from the government in the case of failure; and the improper implementation of the regulations and of the law, because of a poor legal system and corrupt administrationt, represent, in the respondents' opinions, the main problems faced by the business environment and, implicitly, the newly established companies in Brașov. Furthermore, taking into account the high costs of real estate and the unavailability of human resources, the respondents believe that action is needed from local and national authorities, containing a number of facilities to be offered to the newly established companies so as to increase their numbers. Such facilities that would bind them to the local could be a free grant of land in order to build a hall or the renting of spaces belonging to the local authorities in order to develop their business, amoung others.

In addition to the legislative facilities, the managers interviewed believe that stimulating entrepreneurship in order to ensure sustainable development of the region compulsorily entails granting financing facilities. In a respondent's opinion, "the lack of business education and especially the lack of financial education in conjunction with the lack of a nearby high tech business centre (the absence of Silicon Valley effect) can only be compensated by creating a framework for adequate financing and support from the financial institutions that would conceive packages meant to support companies involved in high-tech".

A possible solution could be the establishment of a hub controlled by a local entity, where startups can interact, be mentored, receive consultancy, and connect with potential investors and financial institutions. Business accelerator programmes designed by government also represent solutions proposed by the foreign managers, taken from the model of their origin countries.

The above findings were confirmed by the results of the interviews conducted among the representatives of startups and public institutions, who mentioned the same fields in which startups could scale up. It was mentioned that "Brasov is on the 2nd place in Romania as number of tourists so tourism is one of the most attractive fields for startups". The respondents highlighted that major investments have been made in tourism infrastructure of Brasov, which cover the market demand. However, these accommodation units need services that represent great opportunities for startups. The development of infrastructure and mainly the new airport to be built in the near future are also mentioned as opportunities for startups' development. Such new facilities as well as the existing companies will need IT services, which is considered another challenge for startups. Additionally, it was mentioned that "the large industry should not be considered the main pillar of entrepreneurial ecosystem and the creative business based on innovation are more important". In this respect, the startups' representatives consider that the university, mainly through its IT study programs, can contribute to startups' scaleup in this field. Such arguments are in line with other findings mentioned in literature [2].

Starting with these general opinions concerning the opportunities of startup development, we set out to identify which of the four collaboration models mentioned in the introductory part are used by large companies in their relationship with startups.

(O2) Identifying managers' opinions about the ways in which large companies can contribute to the development of startups

This topic of discussion was split up in the interview guide into four sub-topics. The results related to this objective are presented below, divided according to every sub-topic of discussion.

\section{Advantages of Collaboration with Startup Companies}

During their activity, all research participants declared that they have collaborative relationships with local startups. The main goal is to design goods or services meant to optimize their production, distribution, or sale. The common features of these products are the incorporation of cutting-edge technologies and artificial intelligence and the presence of a strong digital component. In the interviewed managers' opinions, the collaboration between corporations and startups encourages and accelerates innovation, bringing mutual benefits. In this regard, one of the interviewed managers 
said, "As a corporation, we benefit from the entrepreneurial creativity and talent, we teach and bring innovations faster on the market, while the startups benefit from our expertise, infrastructure, network and marketing experience."

In the current environment, where change occurs extremely fast, the corporations have come to the conclusion that they must complement their internal innovation efforts with new ideas from outside the organization. Therefore, startups are vital for the large companies' capacity to innovate fast and to offer better services to clients.

A sustainable corporation bases its success on optimized, efficient, and high-quality processes. This is, however, limited by its capacity to add new businesses to its portfolio. Startups bring speed and flexibility, by the nature of their limited resources, which creates the premises of an ideal approach to the development of new businesses. Therefore, cooperations of startups and corporations can be "win-win" collaborations, offering speed to large companies and resources to startups.

According to a manager of a large company, "The startups are an integral part of our innovation strategy in so far as they give us access to advanced technologies and, by collaborating with them, we are faster in developing and implementing solutions. The collaboration with the startups allows us to be among the first to implement new technologies and capitalize on new business opportunities. Together, we share the passion and the determination to make things come true. We like things to be well-done, the entrepreneurs are good executants and, therefore, we like to collaborate with them." Another respondent emphasized that generating ideas is the main advantage arising from the collaboration with local startups, because they understand the local needs better than large companies, which, in some respects, are inflexible.

The managers also referred to the financial aspects, saying that they appeal to startups also because of their low costs for developing certain products or services; furthermore, they are up-to-date in narrow fields as these products are their object of activity.

The representatives of startups confirmed their collaboration with large companies on a permanent basis or on specific projects, but some of them stated that they are only suppliers for such companies. They would be more interested in being involved in creative activities that could better help them to scale up, which is also highlighted in the literature [43]. The public institutions' representatives also appreciated the necessity of such collaborations, and stated that they currently offer business consultance for startups and also mediate contacts between different companies interested in specific business areas.

\section{Large Companies' Ways of Collaboration with Startups}

In most cases, the collaboration between big companies and startups was achieved by "co-working space" activities, which means that, during the collaboration, the startup is permanently assigned an office within the company, so a team of 2-3 people can carry on with their activity when they require information from and interaction with company's employees. In other cases, it was stated that only the implementation of the processes was done within the company, while the collaboration between the two companies was online.

Only one of the respondents said that his company had the role of accelerator for one of the startups they collaborated with. In this case, the company's support was substantial and connections with other companies were established for the startup, helping it to rapidly scale.

The entrepreneurs asserted that they are very interested in using co-working spaces and other facilities offered by large companies as "accelerators" for startups. Even if they used some co-working spaces inside the large companies, the entrepreneurs consider that special attention should be paid to increasing the number and variety of such facilities, as also mentioned in the literature $[41,42]$. Nevertheless, the startups' representatives stated that, during their co-working activities with large companies, turnover and profitability increased considerably. 
Assessing the companies' possibility to purchase startups or to invest in their capital, most managers stated that, although the collaboration with them is a priority, the purchase is not part of the company's medium-term strategy. The main reason is the differences between the company's activity and that of the startups they work with and, at present, the fact that they do not have the objective of expanding their field of activity. The mutual agreement upon this argument was that, "We only purchase when we consider it appropriate and it is more useful for us to own a certain division than to appeal to collaborators. We solely purchase what is related to "core business" and brings us a competitive advantage. Anyway, the purchase strategy is designed by the corporate board and not by the Romanian branches. Currently, there is no such intention to buy any of the startups we work with; on the contrary, the tendency is to outsource services." Our theoretical framework assumes this idea also supported by authors such as Radziwon and Bogers [59]. Only one of the managers stated that the negotiations for purchasing a startup began, with this purchase not being the first of this kind. The startups' managers also declared that they are not interested in these kind of transactions and that their main focus is on business development.

\section{The Companies' Participation in Events Dedicated to the Startups}

As for the involvement of companies in activities meant to stimulate the generation of ideas, the managers' answers did not differ much. More than half stated that they launched competitions for business ideas or participated as sponsors in "hackathon"-type events dedicated to startups. Only a small number of the companies were not involved in this type of activity, mentioning that startups had come to meet them; startups made the proposals, and afterwards, the resulting instruments were designed through collaboration of both parts.

It can thus be concluded that from the managers' perspective, the collaboration with startups is important for three reasons; that is, it enables the participation in the broader innovation ecosystem, it helps the executives get early signals on technologies that are succeeding in the market, and it allows them to bring innovative enterprise-grade solutions to companies' customers. This is a mutually beneficial dynamic between the startups, the companies, and their customers.

Public institutions are also involved in increasing the startups' exposure by organizing various events, but the participants are mainly new established companies from innovative fields, such as IT. This statement was also confirmed by the representatives of startups that did not participate in such events, with some of them having no information about these opportunities.

Keeping in mind the quadruple helix theory, we proceeded further to identifying the role that universities could play in the development of the entrepreneurial ecosystem of Brasov.

(O3) Identifying managers' opinions about the ways in which the Transilvania University of Brasov can contribute to the development of the entrepreneurial system

This topic was structured in three sub-topics of discussion. The results related to this objective are synthesized below.

The ways in which Transilvania University contributes to the formation and development of graduates' entrepreneurial skills and competences

Ecosystems have a catalytic role in stimulating innovation, because the innovation actors and innovation policy alone are often not enough to drive change, which is why higher education institutions must interact with other actors in innovation [56]. We analyzed the role of Transilvania University in promoting entrepreneurial culture and developing the entrepreneurial ecosystem in Brasov.

Asked if they believe that Transilvania University contributes to the formation and development of graduates' entrepreneurial skills and competences, the respondents unanimously approved, exemplifying which are, in their opinion, the main tools used by university to achieve this goal. Most managers mentioned that, according to their knowledge, the use of digital technology in teaching-learning activities, with a view of developing the relevant digital skills and competences; organizing meetings with entrepreneurs from different fields of activity; and teaching entrepreneurship 
courses are the main methods approached by the Transilvania University of Brasov. They believe that in order to train graduates with entrepreneurial skills, who are customer-oriented, able to work in teams, and prove a "can-do" approach, the startup weekend activities, the idea contests, and the reward for the best pitches, as well as inviting successful entrepreneurs, are very important. They mentioned that such activities regularly take place in Transilvania University. In everyone's opinion, the university helps its students and graduates who want to start a business as a career option, through the newly created structures that offer mentorship and consultancy, and that organize activities meant to encourage the generation of new ideas and the formation of entrepreneurial skills. Nevertheless, half of the respondents appreciate that, in terms of funding, the university does not provide enough support, because there are no funding projects run by the university in order to create startups, but rather the university only connects the students with institutions and organizations that may provide financial support.

The interviewed representatives of startups and public institutions highlighted similar ideas. They consider that the university has to offer a performant entrepreneurship education in which companies, including startups, should be involved. Organizing contests of business ideas or business plans is also considered very useful. Joint projects for graduation theses are considered to be very important by all participants. All the above-mentioned statements are in line with the findings presented in literature, which highlight the crucial role played by academia in developing the entrepreneurial ecosystems [52-55].

The ways in which Transilvania University can collaborate with the business environment in order to develop entrepreneurial education

As for the ways in which Transilvania University can collaborate with the business environment in order to develop entrepreneurial education, respondents issued an impressive number of ideas, which can be grouped in a few categories. Some research participants believe there is a need for a better synergy between education, research, and practice, and consequently an improvement of the university curriculum.

Another category expressed the idea that close links between research and teaching activity should be established by involving doctoral students in approaching research topics in the fields of interest to the business environment.

The third category claims that organizing mentoring and feedback sessions with members of the business community, as well as conducting surveys among the students and graduates who have built a career as entrepreneurs, should be extended to larger groups of students.

All the research participants asserted that it is important to jointly find and develop innovative solutions, which should be disseminated widely. The collaboration with external stakeholders is considered essential for providing extracurricular learning activities and for accustoming students and teaching staff with the companies' expectations and needs. These outcomes are in line with other widely highlighted theoretical approaches [56], which was also confirmed by the representatives of startups and public institutions included in our sample. They consider that the university should act as catalyst of these collaborations, as it has relationships with a large spectrum of economic, social, and public entities.

Measures to be taken by the university with a view to transfer innovation from the university to the business environment

Regarding the measures to be taken by the university with a view to transfer innovation from university to the business environment, all the respondents stated that this goal can be attained only by developing skills around companies' needs, by adapting the academic programmes and by achieving a synergy between business and academia. Prior to making a technology transfer from the university to the business environment, it is necessary for the university to proceed with the implementation of modern education, which can contribute to the formation and development not only of students' 
entrepreneurial skills and competences, but of all the skills required in the labor market. This goal implies renouncing to classical courses, approaching innovative teaching methods, and granting greater autonomy and responsibility to the students in the learning process. This does not mean introducing only entrepreneurship courses into the curricula, but also courses designed in collaboration with representatives of the business environment.

As the exchange of knowledge between the university, industry, business environment, public sector, and society is an important catalyst for organizational innovation, teaching, advanced research, and local development, the visibility of research and cultivation of entrepreneurial spirit must be a preoccupation of all faculties and departments, each of them having contacts with different stakeholders, with different fields of work and research. A proposal from the managers would be to make the doctoral theses in collaboration with companies from various industries. Some of the respondents appreciate that the Transilvania University of Brașov established a Council of Economic, Social, and Cultural Partners, which includes representatives of the main companies and institutions in the region, and which meets twice a year in order to discuss and implement collaborations. The startups' representatives suggested an increased involvement of SMEs in the activity of the university because, at the moment, there is a preference for partnerships mainly with large companies.

The interviewees suggested the adoption of models used by universities from abroad, which have, at the moment, a large number of spin-offs. Moreover, they emphasized the importance of collaborating with Google Romania with a view to develop Google digital workshops that offer training courses in the field of digital marketing, digital marketing events, free and personalized tips for using digital tools, and online marketing. However, although Transilvania University is digitally engaged in teaching, learning, and assessment practices, the mutually agreed upon premise was that, "It would be useful to create a digital incubator to focus on digital economy, startups in cloud computing, IoT, drones and robotics, big data analyses etc. The idea of creating "Google Hub" to support students who want to start a company with the help of their colleagues from Google should be put into practice. Furthermore, it was recommended the development of an online portal to promote employment opportunities and interships for students directly on the university site. Thus, the interested companies can meet students directly through this platform, and the graduates can be also permanently connected with employment opportunities."

An idea expressed by some of the managers participating in the research is that, "The granting incentives and rewards given by university to the ones with entrepreneurial initiatives, to the staff and students who promote university's entrepreneurial agenda, who support and contribute to increase institution's entrepreneurial capacity, should be part of the university strategy. Entrepreneurial goals can only be achieved if the persons throughout the organization are allowed to manifest their own initiatives, to engage in innovation and to develop relationships with external stakeholders."

There is a consensus and a shared vision for all the managers that students' involvement in activities that develop an entrepreneurial way of thinking is essential.

These results are in line with the current strategy of Transilvania University, which focuses on entrepreneurship education to develop and encourage the entrepreneurial mindset among students by organizing activities and events for students. All the activities are concentrated on developing three major directions of action, which are: entrepreneurial education; development and mentoring; and financing entrepreneurial initiatives. The main resources used are seminars with business topics, workshops, mentoring sessions, and even pitching events.

\section{Conclusions and Proposals}

The results of our study confirm the importance of both the academic and business environment to startups and to the development of an entrepreneurial ecosystem, an aspect widely debated in the specialized literature $[10,35,56]$. On the basis of the opinions of the interviewees, the answers to the research questions were obtained. Thus, in response to the first research question (Q1) regarding the ways in which large companies can stimulate the development of startups, there is a high potential for 
the development of startups in Brasov, with the main fields of activity identified by the respondents being the IT industry and the automotive industry, which is highly developed in the area, as well as fields in the sphere of services for population, such as tourism and entertainment. The significant majority ( $88 \%$ ) of the corporations we surveyed have a dedicated open innovation unit with direct report lines to the CEO, Chief innovation Officer, or Chief Digital Officer. It was emphasized that startups are much more flexible and can implement new ideas more easily than the large companies. In this respect, the support of large companies comes in several ways, such as offering workspaces within the company (co-working space) where the startups can develop their activity on different projects; online collaboration and project implementation in mixed teams; and organizing idea contests or sponsoring "hackathon"-type events dedicated to the startups. Open innovation methods vary greatly depending on objectives, size, development stage, sector, and financial and technological resources. On the basis of the collected data, we identified that, from the diversity and richness of collaborative methodologies for open innovation among corporations, only exposure and accelerators programmes continue to be widely adopted. There is the general conviction that the collaborations between corporations and startups are mutually beneficial: startups bring to corporations new opportunities to innovate as well as cultural change, while startups can scale up faster with the resources and established routes to markets in which the corporate is operating.

All these answers confirm one of the research hypotheses, which states that corporations engage with startups by collaborative models. Mostly using the basic model ("exposure"), companies are available to outsource a series of activities that will be assigned to startups. This availability for collaboration is also confirmed by a low interest of the analyzed companies in buying successful startups or using corporate venture capital programmes. Our evidence shows that only the basic models ("exposure and accelerators") are used and almost no complex models are used, which suggests that collaboration between corporates and startups in Brasov is in an incipient phase.

Nevertheless, the development of startups is hampered by a series of environmental factors, among which the poorly developed infrastructure, legislative shortcomings, high costs for renting spaces, and insufficient financial and human resources were mentioned. For these reasons, the entrepreneurial initiatives and development of startups must be supported by both the business environment and stakeholders, such as authorities, non-profit associations, and educational institutions. In this context, the second research question $(\mathrm{Q} 2)$ addressed the ways in which the higher education institutions can contribute to the development of the entrepreneurial ecosystem. The answer to this question focuses on the need for an increased involvement of the students in educational activities meant to stimulate the entrepreneurial spirit. In this regard, a stronger connection between theory, research, and practice, as well as the active involvement of the specialists from the business environment in initiating entrepreneurial projects in which students have a central role, is needed. These results confirm the second research hypothesis, which states that universities play a vital role in the development of the local entrepreneurial ecosystem.

The above-mentioned research results support the theory of the quadruple helix found in the literature, which emphasizes the need to involve several categories of actors, such as the public sector, academia, industry, and citizens, in achieving a sustainable entrepreneurial environment [31].

In conclusion, in Brasov city, the collaboration between the Transilvania University and large corporations might support the establishment and development of local startups. In this way, Brasov can become a startup city for businesses from various activity fields, with its potential being mentioned in the answers of all the interview participants.

Starting from this general conclusion, a few proposals have been outlined for both the business environment and the higher education institutions. Although at present, Transilvania University supports motivated students and graduates in taking their first steps in preparing for a startup, through the organized activities that include startup weekends, the organization of idea and startup pitch prizes, helping entrepreneurs at different stages (developing an idea, finding a team, and exploring the technical and market feasibility of a project), a closer collaboration with the business environment 
would add value to these activities. Thus, the university should involve students in as many projects as possible proposed by the business environment (especially by the large companies), and they should attract specialists from these companies to coordinate the respective projects. These specialists should stay in contact with the students on a permanent basis and conduct mentorship activities meant to provide them with the specialized support for project implementation. Furthermore, the university should provide the conditions for the formation of startup hubs, where the students can set up and develop their own business, benefitting from specialized, logistical, and even financial support. Thus, by intensifying the relationship between the university and business environment, by supporting the students and graduates in setting up their companies, and subsequently by the support granted to startups to scale up, Brasov would be transformed into a startup city. By this collaboration, all participants can obtain material and immaterial benefits and the local business ecosystem could reach sustainable development. Thus, the local entrepreneurs can gain more confidence in their own forces and in the viability of some ideas, knowing that they can receive professional assistance from experts in the field.

As for large companies, the main recommendation is to continue the process of outsourcing some activities that can be provided by startups. By encouraging the newly established enterprises to specialize in producing or supplying certain products or services, large companies can receive a higher added value than that obtained in achieving the respective products/services through its own forces. On the basis of this specialization, the startup can increase its market share by bidding to other companies that need those goods or services. Moreover, it is important for large companies to provide the logistical support for startups, by offering workspaces, as well as access to their own infrastructure or other elements necessary for the smooth development of their activity. Not least, an honest relationship based on mutual gain is required between large companies and the startups they collaborate with in order to stimulate sustainable growth of the second category of enterprises.

Although investment in startups requires significant resources and expertise, the benefits can be compelling, often creating a competitive advantage through exclusive access to cutting-edge technologies and other innovations. For this reason, companies should invest in startups through corporate venture capital funds.

In contrast to past contributions that only deepen an open innovation model, this current research, proposing several models, offers a wider insight into open innovation activities. The authors consider that this paper contributes to a better understanding of how large companies engage startups through various mechanisms, often adapting existing collaborative models with new approaches. Past research on Romanian entrepreneurial initiatives and possible successful fields of entrepreneurship is not enough [62].

In our opinion, we dare say the above proposals can be applied in other cities as well, even if the levels of development of these ecosystems are different, as they have a high degree of applicability and can contribute to the sustainable development of the business environment. Furthermore, the results of our research also have theoretical implications that can be used by the academic environment. Thus, the four collaboration models mentioned above can be the subject of some study topics in the entrepreneurship courses, with an emphasis on the need to capitalize on some market advantages offered by the large companies.

Obtaining sustainable economic growth based on the development of startups should also benefit from the support of other stakeholders, such as professional associations, local and central authorities, and residents, as mentioned in the quadruple helix theory. Such stakeholders often have a decisive role in the development of a startup city. In fact, one of the limits of this research is the non-inclusion of such stakeholders' opinions in the analysis. This is a first study that covers the objectives initially proposed, but that is open to new advances proposed along future lines, because we want to go deeper in finding leverages that a startup city can use to step up its game and unleash its real potential. In this respect, for future research, we aim at identifying the other above-mentioned stakeholders' opinions. 
Another limit of the research is given by the research method employed. As this is qualitative research, the results cannot be generalized, which may reduce the validity of our findings. For this reason, we propose as future research to conduct survey-type quantitative research on large samples, which will include all categories of stakeholders. The goals of these studies will be established starting with the results of this qualitative research.

This paper contributes to this ongoing debate by empirically determining the models of collaboration between large companies and startups in order to accomplish the most successful innovations and create an innovative ecosystem to achieve the goal of establishing a startup city. We consider in our theoretical framework the significant relevance of higher education institutions in the entrepreneurial ecosystem development. Given that, in the literature, the problem of sustainable growth is usually approached separately, either in large companies or SMEs, our study is different in its attempt to highlight the need for collaborative relationships between them, especially between large companies and startups. Thus, both categories of companies can reach a repositioning in the market, from competition to partnership.

Author Contributions: Both authors had equal and significant contributions to this work. Each author contributed in conception, data collection, design, and interpretation of results. Both authors read and approved the final manuscript.

Funding: The research was financed by Transilvania University of Brașov through the project CNFIS-FDI-2019-0057" Antreprenoriatul o variantă pentru susținerea creativității studenților din Universitatea Transilvania (Start-up UTBv)".

Acknowledgments: Both authors would like to thank the managers of the selected companies for their answers and support in achieving this research.

Conflicts of Interest: The authors declare no conflict of interest.

\section{References}

1. Godelnik, R.; van der Meer, J. Sustainable Business Models in an Entrepreneurial Environment. In Sustainable Business Models; Aagaard, A., Ed.; Palgrave Macmillan: Cham, Germany, 2019; pp. 239-276.

2. Kuckertz, A.; Wagner, M. The influence of sustainability orientation on entrepreneurial intentions-Investigating the role of business experience. J. Bus. Ventur. 2010, 25, 524-539. [CrossRef]

3. Drucker, P.F. Innovation and Entrepreneurship: Practice and Principles; Routledge: Abingdon, UK, $1985 ;$ p. 22.

4. Munoz, P.; Dimov, D. The call of the whole in understanding the development of sustainable ventures. J. Bus. Ventur. 2015, 30, 632-654. [CrossRef]

5. Cohen, B. Sustainable valley entrepreneurial ecosystems. Bus. Strategy Environ. 2006, 15, 1-14. [CrossRef]

6. Åstebro, T.; Bazzazian, N.; Braguinsky, S. Startups by recent university graduates and their faculty: Implications for university entrepreneurship policy. Res. Policy 2012, 41, 663-677. [CrossRef]

7. Galvao, A.; Mascarenhas, C.; Marques, C.; Ferreira, J.; Ratten, V. Triple helix and its evolution: A systematic literature review. J. Sci. Technol. Policy Manag. 2019, 10, 812-833. [CrossRef]

8. Luengo, M.J.; Obeso, M. The triple helix effect on innovation performance. Revista Administração Empresas 2013, 53, 388-399. [CrossRef]

9. Etzkowitz, H. The triple helix: Academic-industry-government relations-Implications for the New York regional innovation environment. Ann. N.Y. Acad. Sci. 1996, 787, 67-86. [CrossRef]

10. Sarango-Lalangui, P.; Santos, J.L.S.; Hormiga, E. The Development of Sustainable Entrepreneurship Research Field. Sustainability 2018, 10, 2005. [CrossRef]

11. Binder, J.; Belz, F.M. Sustainable entrepreneurship: What it is. In Handbook of Entrepreneurship and Sustainable Development; Kyrö, P., Ed.; Elgar: Cheltenham, UK, 2014; pp. 30-71.

12. Thompson, N.A.; Kiefer, K.; York, J.G. Distinctions not dichotomies: Exploring social, sustainable, and environmental entrepreneurship. In Social and Sustainable Entrepreneurship (Advances in Entrepreneurship, Firm Emergence and Growth); Emerald Books: Bingley, UK, 2011; Volume 13, pp. 201-229.

13. Staber, U. Specialization in a Declining Industrial District. Growth Change 1997, 28, 475-495. [CrossRef]

14. Isaak, R. The making of the ecopreneur. Green. Manag. Int. 2002, 38, 81-91. [CrossRef] 
15. Walley, E.E.; Taylor, D.W. Opportunists, Champions, Mavericks...? Green. Manag. Int. 2002, 38, 31-43. [CrossRef]

16. Lehmann, M.; Christensen, P.; Møller Larsen, J. Self-regulation and new institutions. The case of green networks in Denmark. In Corporate Environmental Strategy and Competitive Advantage; Sharma, S., Aragón-Correa, J.A., Eds.; Elgar: Northampton, MA, USA, 2005; pp. 286-308.

17. Schaper, M.; Volery, T.; Weber, P.; Lewis, K. Entrepreneurship and Small Business; John Wiley \& Sons: Hoboken, NJ, USA, 2010.

18. Borzaga, C.; Solari, L. The Emergence of Social Enterprise. In Management Challenges for Social Enterprises; Routledge: Abingdon, UK, 2001.

19. Prahalad, C.K. The Fortune at the Bottom of the Pyramid; Pearson Prentice Hall: Upper Saddle River, NJ, USA, 2006.

20. Nicolls, A. Social Entrepreneurship: New Models of Sustainable Social Change; Oxford University Press: Oxford, UK, 2006.

21. Doherty, B.; Haugh, H.; Lyon, F. Social Enterprises as Hybrid Organizations: A Review and Research Agenda. Int. J. Manag. Rev. 2014, 16, 417-436. [CrossRef]

22. Austin, J.; Stevenson, H.; Wei-Skillern, J. Social and commercial entrepreneurship. Some, different, or both? Entrep. Theory Pract. 2006, 30, 1-22. [CrossRef]

23. Desa, G.; Kotha, S. Ownership. Mission and Environment: An Exploratory Analysis into the Evolution of a Technology Social Venture. In Social Entrepreneurship; Mair, J., Robinson, J., Hockerts, K., Eds.; Palgrave Macmillan: Basingstoke, UK, 2006; pp. 155-179.

24. Zahra, S.A.; Rawhouser, H.N.; Bhawe, N.; Neubaum, D.O.; Hayton, J.C. Globalization of Social Entrepreneurship Opportunities. Strateg. Entrep. J. 2008, 2, 117-131. [CrossRef]

25. Schaltegger, S.; Wagner, M. Sustainable entrepreneurship and sustainability innovation: Categories and interactions. Bus. Strategy Environ. 2011, 20, 222-237. [CrossRef]

26. Muñoz, P.; Cohen, B. Sustainable entrepreneurship research: Taking stock and looking ahead. Bus. Strategy Environ. 2017, 27, 1-23. [CrossRef]

27. Schumpeter, J.A. The Theory of Economic Development; Oxford University Press: Oxford, UK, 1942.

28. Hall, J.; Daneke, G.; Lenox, M. Sustainable development and entrepreneurship: Past contributions and future directions. J. Bus. Ventur. 2010, 25, 439-448. [CrossRef]

29. Oviatt, B.M.; McDougall, P.P. Challenges for Internationalization Process Theory: The Case of International New Ventures. Manag. Int. Rev. 1997, 37, 85-99.

30. Crals, E.; Vereeck, L. The affordability of sustainable entrepreneurship certification for SMEs. Int. J. Sustain. Dev. World Ecol. 2005, 12, 173-183. [CrossRef]

31. Porlezza, C.; Colapinto, C. Innovation in Creative Industries: From the Quadruple Helix Model to the Systems Theory. J. Knowl. Econ. 2012, 3, 343-353. [CrossRef]

32. Mason, G.; Bishop, K.; Robinson, C.; Business Growth and Innovation: The wider impact of rapidly-growing firms in UK city-regions. Research Report BGI/36. NESTA. 2009. Available online: https://media.nesta.org. uk/documents/business_growth_and_innovation.pdf (accessed on 31 October 2019).

33. Peltoniemi, M.; Vuori, E. Business ecosystem as the new approach to complex adaptive business environments. Proc. eBus. Res. Forum 2004, 2, 267-281.

34. Tsujimoto, M.; Kajikawa, Y.; Tomita, J.; Matsumoto, Y. A review of the ecosystem concept-Towards coherent ecosystem design. Technol. Forecast. Soc. Change 2018, 136, 49-58. [CrossRef]

35. Tripathi, N.; Oivo, M.; Liukkunen, K.; Markkula, J. Startup ecosystem effect on minimum viable product development in software startups. Inf. Softw. Technol. 2019, 114, 77-91. [CrossRef]

36. Kuckertz, A. Let's take the entrepreneurial ecosystem metaphor seriously! J. Bus. Ventur. Insights 2019, 11, e00124. [CrossRef]

37. Kim, B.; Kim, H.; Jeon, Y. Critical success factors of a design startup business. Sustainability 2018, $10,2981$. [CrossRef]

38. Păunescu, C.; Popescu, M.C.; Duennweber, M. Factors determining desirability of entrepreneurship in Romania. Sustainability 2018, 10, 3893. [CrossRef]

39. Cantamessa, M.; Gatteschi, V.; Perboli, G.; Rosano, M. Startups' roads to failure. Sustainability 2018, 10, 2346. [CrossRef] 
40. Saura, J.R.; Palos-Sanchez, P.; Grilo, A. Detecting indicators for startup business success: Sentiment analysis using text data mining. Sustainability 2019, 11, 917. [CrossRef]

41. Moschner, S.-L.; Fink, A.A.; Kurpjuweit, S.; Wagner, S.M.; Herstatt, C. Toward a better understanding of corporate accelerator models. Bus. Horiz. 2019, 62, 637-647. [CrossRef]

42. Hochberg, Y.V. Accelerating Entrepreneurs and Ecosystems: The Seed Accelerator Mode. Innov. Policy Econ. 2016, 16, 25-51. [CrossRef]

43. Dushnitsky, G.; Lenox, M.J. When do incumbents learn from entrepreneurial ventures? Res. Policy 2005, 34, 615-639. [CrossRef]

44. Gupta, R.; Mejia, C.; Kajikawa, Y. Business, innovation and digital ecosystems landscape survey and knowledge cross sharing. Technol. Forecast. Soc. Change 2019, 147, 100-109. [CrossRef]

45. Kuratko, D.F.; Ireland, R.D.; Covin, J.G.; Hornsby, J.S. A Modle of Middle-Level Manager's Entrepreneurial Behaviour. Entrep. Theory Pract. 2005, 29, 699-716. [CrossRef]

46. Vesper, K.H.; Gartner, W.B. Measuring Progress in Entrepreneurship Education. J. Bus. Ventur. 1997, 12, 403-421. [CrossRef]

47. Zahra, S.A.; KuratkO, D.F.; Jenning, D.F. Guest Editorial: Corporate Entrepreneurship and Wealth Creation: Contemporary and Emerging Perspectives. Entrep. Theory Pract. 1999, 24, 5-8. [CrossRef]

48. McGrath, R.G.; MacMillan, I.C.; Scheinberg, S. Elitists, risk-takers, and rugged individualists? An exploratory analysis of cultural differences between entrepreneurs and non-entrepreneurs. J. Bus. Ventur. 1992, 7, 115-135. [CrossRef]

49. Kickul, J.; Gundry, L. Prospecting for Strategic Advantage: The Proactive Entrepreneurial Personality and Small Firm Innovation. J. Small Bus. Manag. 2002, 40, 85-97. [CrossRef]

50. Hisrich, R.D. Entrepreneurship: Starting, Developing and Managing a New Enterprise; Irwin/McGraw-Hill: Boston, MA, USA, 1998.

51. Kirby, D. Entrepreneurship education: Can business schools meet the challenge? Educ. Train. 2004, 46, 510-519. [CrossRef]

52. Gautam, M.K.; Singh, S.K. Entrepreneurship Education: Concept, Characteristics and Implications for Teacher Education. Int. J. Educ. 2015, 5, 21-35.

53. Acemoglu, D.; Robinson, J.A. Why Nations Fail: The Origins of Power, Prosperity and Poverty; Crown: New York, NY, USA, 2012; p. 529.

54. Rodriguez-Pose, A.; Di Cataldo, M. Quality of government and innovation performance in the regions of Europe. J. Econ. Geogr. 2015, 15, 673-706. [CrossRef]

55. Marques, P.; Morgan, K. The Heroic Assumption of Smart Specialisation: A Sympathetic Critique of Regional Innovation Policy, in New Avenues for Regional Innovation Systems-Theoretical Advances, Empirical Cases and Policy Lessons; Springer International Publishing: Berlin, Germany, 2018.

56. Heinnovate. Available online: https://heinnovate.eu/en (accessed on 12 August 2019).

57. Tempo online. Available online: http://statistici.insse.ro:8077/tempo-online/\#/pages/tables/insse-table (accessed on 1 May 2019).

58. ONRC. Available online: www.onrc.ro/index.php/ro/statistici (accessed on 1 May 2019).

59. Radziwon, A.; Bogers, M. Open innovation in SMEs: Exploring inter-organizational relationships in an ecosystem. Technol. Forecast. Soc. Change 2019, 146, 573-587. [CrossRef]

60. Onwuegbuzie, A.J.; Dickinson, W.B.; Leech, N.L.; Zoran, A.G. A qualitative framework for collecting and analyzing data in Focus Group Research. Int. J. Qual. Methods 2009, 8, 1-21. [CrossRef]

61. Decrop, A. Triangulation in qualitative tourism research. Tour. Manag. 1999, 20, 157-161. [CrossRef]

62. Nicolau, C.; Foris, T. Human Resources in Crisis: Identifying future entrepreneur's profile in Romania. Proc. Soc. Behav. Sci. 2018, 238, 572-581. [CrossRef]

(C) 2019 by the authors. Licensee MDPI, Basel, Switzerland. This article is an open access article distributed under the terms and conditions of the Creative Commons Attribution (CC BY) license (http://creativecommons.org/licenses/by/4.0/). 